\title{
How Great Expectations in Brussels are dashed in Tunis? A Bottom-up approach to the Implementation of the European Neighbourhood Policy in Tunisia
}

\author{
By Iole Fontana*
}

\begin{abstract}
The literature on the ENP has traditionally adopted a top-down approach that frames the policy and its implementation from the EU point of view, by starting from the authoritative decision and analyzing the role of the EU centrally located actors and their instruments. While this "inside-out" perspective is fundamental, still it is not able to fully capture the "dilemmas of the implementation" that lay behind EU external policies. These studies are context free and do not shed light on how implementation actually works on the local ground in the recipient countries. The goal of this paper is to adopt a "reversed focus" in the implementation analysis of EU external policies. It argues that the top down perspective provides just a frame of explanation and that it should be integrated by a bottom-up approach able to highlight the peculiarities of the microimplementing environment. For this purpose, the ENP in Tunisia is adopted as a case study.
\end{abstract}

\section{Introduction}

Within the "art and craft" of European Union (EU) external policymaking, implementation is one of the most "artistic" and problematic aspects, an interactive endeavor that ultimately depends upon the skillful hands of multiple actors for success. Of the many EU external policies that embody this "complexity of joint action" (Pressman \& Wildavsky, 1984), the European Neighborhood Policy (ENP) is indeed a case in point. As one of the main venues for Euro-Mediterranean Relations, in the last decade the ENP has set up several budgetary instruments and financial programs to address a broad array of objectives in the name of political and economic reforms. In this regard, the policy and its implementation were blamed for the recipient countries' slow uptake of reforms, feeding the traditional idea of a gap between EU rhetoric and practice. As the Arab Spring shockwave crossed the Mediterranean, the ENP record has come even more under the spotlight.

Traditionally, the literature on the ENP has adopted a top-down approach that frames the policy and its implementation from the EU point of view, by

${ }^{*}$ PhD Student, IMT-Institute for Advanced Studies, Italy. 
focusing on the limits of the EU approach in terms of policy content and goals (Bosse, 2007; Pace, 2007; Panebianco, 2008); instruments and outcomes (Tovias, 2010; Casier, 2010; Bicchi, 2010b). This kind of analysis reflects a more general trend to the study of EU external policies and their implementation that is characterized by a goal-achievement bias and a focus on the role of EU institutions in carrying out the policies. While this "inside-out" perspective is fundamental, still it is not able to fully capture the "dilemmas of the implementation" (Bicchi, 2010a) that lay behind EU external policies. The greatest bulk of these studies is context free and does not shed light on how implementation actually works on the local ground and on how the EU interacts with local actors in the recipient countries.

The adoption of a "top down" perspective alone, by starting from the authoritative decision and analyzing the role of the EU centrally located actors and their instruments, fails to fully account for implementation and its gaps in the domain of external policies. The final implementation of external policies inevitably depends upon the interaction with third countries and upon their domestic conditions. As suggested by implementation research, implementation is as a complex and multi-actor process (O'Toole, 2000), whose successful realization is conditional on the skills of the local implementation structure to adapt the policy to local conditions (Hjern \& Porter, 1981). In a similar fashion, the implementation of the ENP cannot be given for granted as an automatic process linearly following from the policy objectives defined in the Action Plans. "The passage [of legislation] does not guarantee implementation according to the legislative intent" (Kingdon, 1995:3), as the policy realization is conditional on external circumstances (Pressman \& Wildavsky, 1984) and on the contextual factors within the implementing environment (Matland, 1995).

Local players and context's constraints and features are fundamental explanatory variables ultimately impinging upon the implementation of the ENP in the Mediterranean. They reveal that Brussels has to deal with different outcomes as generated by the different manner in which its policy has been implemented in Tunis or in Rabat. Furthermore, in the post- Arab Spring environment where some of the old constraints disappear while others continue to stand, and where the stage is set for new political actors, implementation and local conditions become even more important.

How is the ENP implemented on the ground in Mediterranean countries? Which local variables do account for implementation and its gaps? How did the Arab Spring impinge upon the implementation of the EU policies? On the assumption that both politics and polity determine policy and on the idea that implementation arises from the interaction of the policy and the local setting (Berman, 1978), the goal of this paper is to adopt a "reversed focus" in the analysis of the ENP by studying the current reality on the ground. For this purpose, Tunisia is selected as a case study. Among the countries of the ENP, Tunisia has shown mixed results and has emerged as the "bad" because of its closure to turn economic success into political opening (Bicchi, 2010b). Secondly, the regime change provoked by the Arab Spring makes the country 
an interesting case to analyze the importance of local conditions in the implementation of the ENP.

By relying on the theoretical underpinnings of policy and implementation analysis, the paper argues that when it comes to the analysis of EU external policies, the traditional top-down perspective provides just a frame of explanation, which should be integrated by a bottom-up approach. The first part of the paper develops the theoretical framework, while the second applies it to the case of Tunisia.

\section{Implementation Theory and EU External Policy-Making: Looking for a "Reversed Focus"}

Implementation is the translation of a policy into action (Barrett, 2004) by a wide range of instruments and actors. It is a complex process where the mere execution of the policy (process) does not automatically imply the goals' achievement (outcomes). Pressman and Wildavsky's (1984) work "How great expectations in Washington can be dashed in Oakland" gives a flavor of these difficulties by convincingly pointing out how the implementation of a largescale federal project can be very difficult. Against the background of several "decision points" which must be passed during the implementation process, of different perspectives and of asymmetric relations between the formulators and the implementers, it is very easy that the "high hopes of the center are dashed against the rocks of the periphery" (Dimitrakopoulos \& Richardson, 2001).

If Pressman and Wildavsky (1984) wonder how policy programs in a federal system can work at all, it is not surprising to detect implementation problems in a multi-level governance system as the EU, where the policy process goes through different levels and final implementation relies upon the will and capability of national political systems (Dimitrakopoulos \& Richardson, 2001; Richardson, 2001). If implementation is a complex process for the policy-making within the EU, it is even more convoluted when it comes to EU external policy-making. In this field, EU's external action range from security to development cooperation and makes use of several financial instruments to achieve the goals of its external policies. While the latter are formulated in the institutional settings of the European External Action Service, the Commission, the Council and the Member States, final implementation inevitably lies in coordination and interaction with the third countries that are the final recipients of the policy and whose will, local conditions and capability guarantee implementation on the ground. For instance, in the neighborhood and in the development cooperation, the EU makes use of both budget support, based on a direct disbursement into the country's national treasury, and decentralized projects, where payments may be devolved to local authorities or non-governmental actors. In both cases, local actors are "veto-points" that lengthen the chain of command and increase the chances to take different directions from the originally intended course (Bicchi, 2010a). Actors on the ground, therefore, resemble what bottom-up 
implementation studies call as the "street-level bureaucrats" (Lipsky, 1980), i.e. the final actors whose discretion and capability impinge upon the translation of the policy into action.

How to analyze and explain the implementation of EU external policies in third countries? In this regard, the literature is often dominated by a "goal achievement bias" which tends to focus on outcomes while underplaying processes. However, the assessment of implementation in terms of impactloutcomes (i.e. the goals achievement) should be preceded by adequate analyses of the implementation as a process (i.e. the modes of execution and the practices on the ground). Outcomes cannot be properly assessed without looking at the processes, i.e. before investigating the gap between EU promises and performances "evaluators have to know [...] what went wrong and why" (Pressman and Wildavsky, 1984: xvi).

Any assessment of policy "success" or "failure" in terms of outcomes should be preceded by an analysis of how the policy is implemented. To better grasp the notion of implementation as a process, it is possible to recall the distinction between implementation "output" and "outcome" (Hill \& Hupe, 2002). While the "outcome" asks the question "do the activities have any effect on the problem?", the "output" concerns "implementation behavior" by asking the questions: "are the specified activities established?" and "how is the policy being implemented by the implementation agency?" (ibid.). An analysis of EU external policies' implementation, therefore, should focus on processes in order to explain the why of specific outcomes. In other words, as O'Toole, (2000: 273, quoted in Hill and Hupe 2002: 8) puts it, "what happens between the establishment of policy and its impact in the world of action?". However, in order to understand what went wrong and why, it is necessary to point out the casual explanatory factors that affect implementation processes. "Evaluators are able to tell us a lot about what happened - which objectives, whose objectives, were achieved - and a little about why - the causal connections" (Pressman and Wildavsky 1984: 203). What are the factors that influence the process of implementation and that may explain its gaps?

While adopting different perspectives, top-down and bottom-up approaches are both addressed to understand the factors that facilitated or constrained implementation and that have caused difficulty in reaching the stated goals (Hill and Hupe, 2002). Top-down approaches (Pressman \& Wildavsky, 1984; Sabatier \& Mazmanian, 2005; Van Meter \& Van Horn, 1975) start the analysis from the authoritative decision; policy designers are the central actors and the attention is on the factors that can be manipulated at the central level. A direct causal link is assumed between policies and observed outcomes and tends to disregard the impact of implementers on policy delivery (Pulzl \& Treib, 2006). Therefore, the main variables are the clarity and the consistency of the policy goals, the number of actors, the extent of required change, the commitment of implementation officials to the program's goals. Along these lines, a top-down analysis to EU external policies and to the ENP starts from the policy goals set forth in policy decisions (e.g. Action Plans) and looks for the actions that are directed at the achievement of the objectives. As 
the attention is on the elements that can be manipulated at central level, implementation gaps are explained from EU stance, by assuming a direct link between the policy and its observed outcomes. In this context, problems in implementation stem from inconsistencies and lack of genuine goals (Bosse 2007; Pace 2007; Panebianco 2008); long chains of commands that from Brussels to the Delegations produce small deviant steps (Bicchi, 2010a), or lack of adequate incentives and sanctions from the EU (Bicchi 2010b; Joffé, 2008; Schimmelfenning \& Scholtz, 2008).

While insightful, the top-down perspective alone provides just a frame of explanation and, by overlooking the contextual factors within the implementing environment of recipient countries, it fails to fully account for implementation gaps in EU external policies. Bottom-up theories (Berman, 1978; Hjern and Porter, 1981; Lipsky, 1978), instead, provide a "reversed focus" as they study what actually happens on the recipient level and analyze the real causes that influence action on the ground (Pulzl and Treib 2006). Implementation problems originate from the interaction of the policy and the micro-level setting (Berman 1978) and central planners cannot influence micro-level factors. The attention, therefore, goes to "street-level bureaucrats" and service deliverers whose capacities and patterns of coordination influence implementation.

A bottom-up analysis to EU external policies allows to scrutinize the domestic context of the recipient country and to explain implementation gaps through the identification of the micro-level peculiarities that influence the process. In particular, by drawing on Hjern and Porter (1981), the attention can be focused on the "implementation structures" that are responsible for the execution of EU policy on the ground, i.e. the networks of actors involved in the implementation of a program. As these structures are defined in terms of a "pool" of public and private organizations whose capacities and coordination impinge upon implementation, the notion can be disentangled by focusing on the actors involved. Two main variables are identified: the administrative/ institutional capacities and the role of civil society/non-state actors.

The importance of administrative/institutional capacities is recognized as crucial not only in classic implementation studies but also in the literature on Europeanization, foreign aid and development ${ }^{1}$. Research suggests that institutions and administrative capability affect implementation, as the ability to fully and effectively manage the policies (Prichett et al. 2010; Lampinen \& Uusikylä, 1998). Institutions can be defined as the institutional structures (ministers, agencies, departments etc) that are in charge of carrying out the required functions. In this regard, administrative capacities are intended as management and coordination. The former is the capability of overseeing the correct implementation of the overall programme (Milio, 2007). The latter concerns the correct coordination among the different actors and levels. While EU external policies involve different actors within the recipient country, usually there is always one main institutional actor (e.g. a specific minister)

\footnotetext{
${ }^{1}$ See Mbaye (2001); Talberg (2002); Guillaumount (2007); Paul (2006).
} 
that acts as a central coordinator and that should be responsible for the division of competence.

Civil society and non-state actors are another crucial component of implementation stage in the policy process. In particular, while Smith (1973) stresses the role of interested groups, Brinkerhoff (1999) analyzes the participation of civil society organizations in implementation and their capacity to influence the process. Against this background, civil society in the recipient country is an important variable influencing the implementation of EU external policies. In the case of the ENP, while the policy is mainly intergovernmental and executed primarily by the state and its administration, private actors and representatives of civil society are constantly involved as part of the program's stakeholders. This involvement is even stronger in the case of those instruments of external assistance that directly address civil society (e.g. the European Instrument for Democracy and Human Rights). The role of civil society can be operationalized by considering its capacity to influence implementation process. In this regard, the main indicators are the relative strength of the state vis-à-vis civil society and the latter's degree of independence, by keeping in mind that the regime type and the existing legal and institutional framework (e.g. restrictive regulations; obstacles to freedom of association) influence the "space" available to civil society (Brinkerhoff, 1999).

Finally, while this "reversed focus" to the implementation of the EU external policies is based on an actor-centered bottom-up approach, structural conditions cannot be neglected (Sabatier, 1986). Socio-economic changes constrain or facilitate actors' behavior. Against this background, if both the Euro-zone economic crisis and the Arab Spring are intervening variables that definitely affect the implementation structures in the neighboring Mediterranean countries, for the purpose of this work I mainly focus on the Arab Spring and its impact on the implementation of the ENP.

\section{The Implementation of ENP in Tunisia: A Bottom-up Approach}

Tunisia was one of the first countries in the neighborhood to sign an Action Plan with the EU in 2005. Since then, the EU has provided more than 500 million Euro, mainly through the European Neighborhood Policy Instrument (ENPI). The ENPI provides assistance through two sets of programmatic documents: the National Indicative Programs (NIP), which define the priorities for action in the time spans 2007-2010 and 2011-2013, and the Annual Action Programs (AAP), that identify specific projects to be launched each year according to the priorities set in the NIPs.

The implementation of the ENP in Tunisia has been characterized by mixed results. While before the Arab Spring the implementation of political reforms was a failure, in the economic and social sector Tunisia's performance was moderately satisfactory, even if displaying some difficulties. In the domain of political reforms, Ben Ali's regime and a stifled civil society where NGOs 
were constrained by cumbersome administrative regulations (Tunisia ENP Progress Report, 2006) impeded the agreement on projects addressed to political reforms. Under the MEDA, the financial instrument that preceded ENPI, the justice project was delayed by lengthy negotiations while the NGO project was cancelled (NIP 2007-210). It is because of these difficulties that the first NIP decided to focus merely on economic governance, employability and development. Only after the regime change paved by the uprisings, political goals such as the reform of justice were eventually agreed.

Here, the analysis will focus on a specific project, the "Appui à l'integration economique" (PAI) which was launched by the AAP 2008 and renewed in 2011 after the Arab Spring. The PAI is a broad project addressed to growth and employment in order to improve the competitiveness of Tunisian economy and its world integration. Based on untargeted budget support, the funds are transferred to Tunisian national treasury by different tranches, whose disbursement is conditional on specific conditions of macro-economic stability and on performance. For the purpose of a bottom-up approach to the ENP implementation, the PAI is an interesting case for two reasons. First, it is a broad project involving different actors and policy sectors. Secondly, as it was re-launched after the Arab Spring, the PAI (later PAR- Programme d'appui à la Relance) allows a certain continuity of analysis. In this way, it is possible to assess differences in the formulation of the program and its implementation before and after the revolutionary shockwave.

As it is a broad program, the "implementation structure" is very complex and it emerges as a network involving a wide range of actors in terms of ministers, departments, specialized institutes, trade unions. The main implementing agency and the central coordinator is the Ministry of Planning and International Cooperation, which is the governmental actor in charge of budget support operations from international donors. The minister of finances, of commerce and industry, together with the DG Douganes and the National Institute for Industrial Property and Normalization (INNORPI), trade unions such as UTICA (Union Tunisienne de l'industre et de l'artisanat) and UTAP (Union Tunisienne of Agriculture and Peche), and finally the advisory groups of enterprises ${ }^{2}$, are only some of the actors involved.

While Tunisian administration is deemed as generally competent (ENP Progress Reports), poor coordination and the absence of a systemic and strategic framework are some of the main problems in implementation. The government of the country is made up of 25 ministries, organized through ministers, vice-ministers and DG, and 11 agencies (CAPSTONE PROJECT, 2012). This inevitably impinges upon the implementation of the ENP projects. Indeed, in the case of PAI, because of the broad array of actors, lack of coordination problematically affected the implementation of the different components of the program. For instance, in the domain of tariff structure simplification and quality norms standardization, while the government issued

\footnotetext{
${ }^{1}$ Support to Economic Integration. See the Tunisian Annual Action Plan 2008, Action Fiche. http://ec.europa.eu/europeaid/documents/aap/2008/af_aap_2008_tun.pdf

${ }^{2}$ http://www.portail.finances.gov.tn/formalites/
} 
a decret with the aim to set in place the modalities for the selective control of imported products, the implementation was delayed for the lack of the technical coordination with the customary agencies ${ }^{1}$. Similarly, in the domain of external trade, inefficient and cumbersome procedures, multiple "vetopoints" and manually exchanged documents lengthened the chain of command of daily implementation ${ }^{2}$. These problems are further exacerbated if analyzed against an institutional setting that, at least during Ben Ali's regime, was extremely rigid and left no options for flexibility or institutional reorganization.

Coordination and administrative capacities problems affected the implementation of the program also in its renewed version (PAR) as defined after the Arab Spring. In order to address the demands of civil society as expressed through the revolution, the renewed program is much broader, by including governance reforms. While one of the new-programmed actions envisages the improvement of administrative transparency, so far proactive diffusion of information by the administration has made limited progress because of the lack of clear rules. In March 2011, the new government introduced an "Unemployment support program" with the purpose to provide unemployment stipends and vocational training. Anyway, faced with a huge number of requests, the limited administrative capacity of the employment agency resulted in a lack of program implementation. Similarly, the new institutional coordination mechanism envisaged for decentralized health and education services was not established ${ }^{3}$. Coordination and administrative issues, anyway, should be analyzed against the revolutionary context, which made project implementation more difficult as it increased political and institutional instability. Uncertainty, leadership changes and administrative turnovers produced delays and implementation difficulties.

Civil society and non-state actors are another crucial component in implementation process. Under Ben Ali's regime, cumbersome administrative regulations stifled NGOs' registration, activities and possibility to accept money from foreign donors. The direct consequence for the EU was not only the impossibility to finance decentralized projects tailored to civil society's organizations, but also the difficulty to target budget support to political reforms. Similarly, the development of private economic sector was severely constrained by costly controls and regulations while the registration of business associations met the same difficulties as NGOs ${ }^{4}$. These problems hindered the success of PAI and other ENP competitiveness programs. Through the revolution and in its aftermath, civil society expanded its degree of power with a mushrooming of civil and business organizations. Given the new context, for the first time politically sensitive areas were covered by the ENP with specific

\footnotetext{
${ }^{1}$ World Bank Report, Evaluation and Completion of the Governance and Opportunity Development Loan, http://wwwwds.worldbank.org/external/default/WDSContentServer/WDS P/IB/2013/01/08/000350881_20130108093901/Rendered/PDF/NonAsciiFileName0.pdf

${ }^{2}$ World Bank Report on External Development Loan

${ }^{3}$ World Bank Report, Evaluation and Completion of the Governance and Opportunity Development Loan, http://wwwwds.worldbank.org/external/default/WDSContentServer/WD SP/IB/2013/01/08/000350881_20130108093901/Rendered/PDF/NonAsciiFileName0.pdf

${ }^{4}$ Delegation EU-Tunisie, Rapport de diagnostic sur la societé civile tunisienne
} 
reforms in the domain of governance and justice. Yet, while the new PAR envisages the development a genuine participatory approach of civil society with a full involvement of the private sector, the latter's lack of experience in voicing concerns to administration has delayed implementation processes ${ }^{1}$. Cooperation and dialogue between public and private is still underdeveloped. Furthermore, while after Ben Ali new union confederations have developed, they still face a strong competition from the UGTT (Bishara, 2014), which remains one of the main actors in the implementation of EU economic programs, whether through budget support or decentralized projects.

Against this background, the Arab Spring is a facilitating condition for the implementation of the ENP, by widening the scope for reform even to those sectors that few years ago were not even open to discussion. Yet, the revolution is as a constraining condition too. Political uncertainty, the instability of the transition and the social tensions provoked by a delicate economic situation affect the pace of implementation. Furthermore, the volatility of the postrevolutionary environment, the change of political leadership and the frequent turnover of ministers impinge upon the already limited coordination and communication capacities within administration.

\section{Conclusions}

While insightful, a "top down" perspective to the study of EU external policies provides just a frame of explanation, as it overlooks the conditions of the implementing environment and therefore fails to fully account for implementation and its gaps. On this point of view, the analysis of the interaction with local actors and domestic conditions is a "missing link" (Robichau \& Lynn, 2009) in the study of EU policy-making towards third countries. While Europeanization and enlargement literatures deal with the question of the extent to which member and candidate states "make European policies work" (Siedentopf \& Ziller, 1988), here the question is the extent to which neighbor and third countries make EU external policies work. The paper provides a "reversed focus" through a bottom-up analysis that is worthy of further analysis and that reveals that great expectations in Brussels can be dashed in the neighboring countries. By adopting the ENP in Tunisia as a case study, administrative capacities, inter-organizational coordination, and the role of civil society are analyzed as independent variables that affect implementation processes.

\section{References}

Barrett, S. (2004). Implementation Studies: Time for a Revival? Personal Reflections on 20 years of implementation studies . Public Administration, 8(2), 249-262.

\footnotetext{
${ }^{1}$ World Bank Report on External Development Loan
} 
Berman, P. (1978). The Study of Macro- and Micro- Implementation. Public Policy, 26(2), 157-184.

Bicchi, F. (2010a). Dilemmas of Implementation: EU Democracy assistance in the Mediterranean. Democratization, 17(5), 976-996.

Bicchi, F. (2010b). The impact of the ENP on the EU-North Africa Relations: the good, the bad and the ugly. In R. Whitmann, \& S. Wolff (A cura di), The European Neighbourhood Policy in Perspective (p. 206-222). New York: Palgrave MacMillan.

Bishara, D. (2014). Labor Movements in Tunisia and Egypt. SWP Commentary, German Institute for International and Security Affairs(1).

Börzel, T. (2001). Non Compliance in the European Union. Pathology or Statistical Artefact? . Journal of European Public Policy, 8(5), 803-824.

Bosse, G. (2007). Values in the EU's Neighbourhood Policy: Political Rethoric or Reflection of a Coherent Policy? European Political Economic Review, 7, 38-62.

Brinkerhoff, D. (1999). State-Civil Society Networks for Policy Implementation in Developing Countries. Review of Policy Research, 16(9), 123-147.

CAPSTONE PROJECT. (2012). Building capacities for governance-Assessing the training needs of Tunisian civil service. Final Report, International Policy and Leadership Institute.

Casier, T. (2010). The European Neighbourhood Policy: Assessing the EU's Policy toward the Region. In F. Bindi, The Foreign Policy of the European Union. Assessing Europe's role in the World (p. 99-115). Washington: Brookings Institution Press.

Dimitrakopoulos, D., \& Richardson, J. (2001). Implementing EU Public Policy. In J. Richardson (A cura di), European Union Power and Policy-Making (p. 335-356). New York: Routledge.

Guillaumount, P. (2007). More than volume of aid: its modalities matter. CERDI Etudes.

Hill, M., \& Hupe, P. (2002). Implementing Public Policy: Governance in Theory and in Practice. London: SAGE.

Hjern, B., \& Porter, D. (1981). Implementation Structures: a new unit of administrative analysis. Organization Studies, 2, 211-227.

Joffé, G. (2008). European Policy and the Southern Mediterranean. In H. Zoubir, \& H. Amirah-Fernandez (A cura di), North Africa: Politics, Religion and the Limits of Transformation (p. 311-330). New York: Routledge.

Kingdon, J. (1995). Agendas, Alternatives and Public Policy. Longman Edition.

Lampinen, R., \& Uusikylä, P. (1998). Implementation Deficit- Why member states do not comply with EU directives? Scandinavian Political Studies, 21(3), 231-51.

Lipsky, M. (1980). Street-level bureaucracy: dilemmas of the individual in public services (30th Anniversary expanded edition ed.). New York: Russel Sage Foudation.

Matland, R. (1995). Synthesizing Implementation Literature: The Ambiguity-Conflict Model of Policy. Journal of Public Administration Research and Theory, 2(5), 145-174.

Mbaye, H. (2001). Why National States Comply with Supranational Law: Explaining Implementation Infringements in the European Union, 1972-1993. European Union Politics, 2, 259-281.

Milio, S. (2007). Explaining differences in regional performance: administrative capacities and political factors. PhD Thesis: London School of Economics and Political Science. 
O'Toole, L. J. (2000). Research on Policy Implementation: Assessment and Prospects. Journal of Public Research and Theory, 10(2), 263-288.

Pace, M. (2007). Norms shifting from the EMP to ENP: the EU as a norm entrepreneur in the South. Cambridge Review of International Affairs, 20(4), 659675.

Panebianco, S. (2008). The EU involvment in the Mediterranean: changing priorities and strategies. ISIG Journal - Quarterly of International Sociology, 3(4), 115128.

Paul, E. (2006). A survey of theoretical economic literature on foreign aid. Asian Pacific Journal.

Pressman, J., \& Wildavsky, A. (1984). How great expectations in Washington are dashed on Oakland: or why it's amazing that federal programs work at all. (Third Edition ed.). California: University of California Press.

Prichett, L., Woolcock, M., \& Andrews, M. (2010, December). Capability Traps? The Mechanisms of Persistent Implementation Failure. Center for Global Development, Working Paper n.234.

Pulzl, H., \& Treib, O. (2006). Implementing Public Policy. In F. Fischer, G. Miller, \& M. Sidney (A cura di), Handbook of Public Policy Analysis: Theory, Politics and Methods (p. 89-107). CRC Press.

Richardson, J. (2001). Policy-making in the EU: interests, ideas and garbage cans of primeval soup. In J. Richardson (A cura di), European Union power and policymaking. New York: Routledge.

Robichau, R., \& Lynn, L. (2009). The Implementation of Public Policy: still the missing link. Policy Studies Journal, 37(9), 21-36.

Sabatier, P. (1986). Top-down and Bottom-up approaches to implementation research: a critical analysis and suggested synthesis. Journal of Public Policy, 6(1), 21-48.

Sabatier, P., \& Mazmanian, D. (2005). The implementation of public policy a framework of analysis . Policy Studies Journal, 8(4), 538-560.

Schimmelfenning, F., \& Scholtz, H. (2008). EU Democracy Promotion in the European Neighbourhood. European Union Politics, 9(2), 187-215.

Siedentopf, H., \& Ziller, J. (1988). Making European Policies Work: Comparative Syntheses. London: SAGE.

Smith, T. (1973). The Policy Implementation Process. Policy Sciences, 4, 197-209.

Talberg, J. (2002). Paths to Compliance: Enforcement, Management and the European Union. International Organization, 56(3).

Tovias, A. (2010). The EU and the Mediterranean non Member States. In F. Bindi, The Foreign Policy of the European Union: assessing Europe's role in the world (p. 160-82). Washington: Brookings Institution Press.

Van Meter, D. S., \& Van Horn, C. (1975). The Policy Implementation Process: a conceptual framework. Administration and Society, 6, 445-488. 
